\title{
Polymorphism Identification, RH Mapping, and Association Analysis with the Anxiety Trait of the Equine serotonin transporter (SLC6A4) Gene
}

\author{
Yukihide MOMOZAWA ${ }^{1)}$, Yukari TAKEUCHI ${ }^{1) *}$, Teruaki TOZAKI ${ }^{2)}$, Takefumi KIKUSUI ${ }^{1)}$, Telhisa HASEGAWA ${ }^{3)}$, \\ Terje RAUDSEPP ${ }^{4)}$, Bhanu P. CHOWDHARY ${ }^{4)}$, Ryo KUSUNOSE ${ }^{3)}$ and Yuji MORI ${ }^{1)}$ \\ ${ }^{1)}$ Laboratory of Veterinary Ethology, The University of Tokyo, 1-1-1 Yayoi, Bunkyo-ku, Tokyo 113-8657, ${ }^{2)}$ Departments of Molecular \\ Genetics, Laboratory of Racing Chemistry, 1731-2 Tsuruta-machi, Utsunomiya-shi, Tochigi 320-0851, ${ }^{3)}$ Equine Research Institute, \\ Japan Racing Association, 321-4 Tokami-cho, Utsunomiya-shi, Tochigi 320-0856, Japan and ${ }^{4)}$ Department of Veterinary Integrative \\ Biosciences, College of Veterinary Medicine and Biomedical Sciences, Texas A\&M University, College Station, Texas, 77843, U.S.A.
}

(Received 6 December 2005/Accepted 24 January 2006)

ABSTRACT. Equine anxiety trait is considered an important temperament in various situations, including riding, training, and daily care. This study examined the polymorphism of the equine serotonin transporter (SLC6A4) gene as a candidate genetic element influencing equine anxiety trait. The sequence of the coding region of this gene was highly homologous with those of other mammals, and four single nucleotide polymorphisms were found by comparing the sequences of ten genetically unrelated thoroughbred horses. Radiation hybrid mapping revealed that this gene was located $26.92 \mathrm{cR}$ from neurofibromin 1 on ECA 11 . Using two-year-old thoroughbred horses $(n=67)$, the association of these polymorphisms with the anxiety trait was examined, but no significant association was identified between each haplotype of the serotonin transporter gene and the anxiety score.

KEY WORDS: anxiety, equine, serotonin transporter.

J. Vet. Med. Sci. 68(6): 619-621, 2006

Differences in the temperaments of individual animals are thought to arise, at least in part, from polymorphisms in genes involved in neurotransmitter pathways, such as transporters, enzymes, and receptors, which in turn influence the activity and turnover of neurotransmitters, such as dopamine, serotonin, and noradrenalin [5]. Based on this concept, polymorphisms in neurotransmitter-related genes have been identified and their associations with various temperament traits have been reported in humans [15] and dogs $[6,16]$. In horses, we reported an association between a single nucleotide polymorphism (SNP) in the dopamine receptor D4 gene and temperament traits, such as 'Curiosity' and 'Vigilance' [12].

In the present study, we focused on polymorphisms of the serotonin transporter (SLC6A4) gene as a candidate genetic element influencing equine anxiety trait, given that this trait is considered particularly important for horses in various situations, including riding, training, and daily management. The serotonin transporter gene plays an important role in regulating serotonin (5-hydroxytryptamine) function by controlling the reuptake of serotonin from the synaptic gap. In humans, a common polymorphism in the promoter region are associated with the harm avoidance trait [7] and this association was confirmed by some additional researches [14]. In this study, we determined the sequence of the equine serotonin transporter gene, screened the gene for polymorphisms, assigned it to an equine chromosome using an equine 5000-rad radiation hybrid $(\mathrm{RH})$ panel [3], and carried out association study with equine anxiety trait using 67 thoroughbred horses.

\footnotetext{
* Correspondence to: Takeuchi, Y., Laboratory of Veterinary Ethology, The University of Tokyo, 1-1-1 Yayoi, Bunkyo-ku, Tokyo 113-8657, Japan.
}

The sequence of the equine homolog of the serotonin transporter gene was obtained using RT-PCR and rapid amplification of cDNA end (RACE) methods with mRNA obtained from the brain of a thoroughbred horse and consensus primers based on other mammals, i.e. human (accession number: X70697), cattle (AF119122), rat (X63253), and mouse (AF013604). A contiguous 1893-bp sequence that contained an open reading frame encoding 630 amino acid residues was found (AB098561). The amino acid sequence had $93.5,91.6,89.3$, and $91.1 \%$ identity with those of human, cattle, rat, and mouse, respectively. In addition, two bands were obtained with the 3'-RACE method using primer F1750, as shown in Fig. 1A, which suggested alternative splicing in the 3 ' untranslated region. Sequence analysis revealed that the poly A tails started 678 and 549 bp downstream from the stop codon, as is the case with humans [1].

To search for polymorphisms in this gene, we determined the sequences of mRNAs derived from the brains of ten genetically unrelated thoroughbred horses. PCR was performed with $100 n \mathrm{~g}$ cDNA in a $50-\mu l$ reaction volume, which consisted of $5 \mu l$ of $10 \times$ AccuPrime PCR Buffer I, $0.2 \mu \mathrm{M}$ of each primer (F-65 and R2402), and 1 unit of AccuPrime Taq DNA Polymerase High Fidelity (Invitrogen, Carlsbad, CA). After an initial denaturation at $94^{\circ} \mathrm{C}$ for 2 min, PCR was performed with 35 cycles of $94^{\circ} \mathrm{C}$ for 30 sec, $54^{\circ} \mathrm{C}$ for $30 \mathrm{sec}$, and $68^{\circ} \mathrm{C}$ for $150 \mathrm{sec}$. The final cycle was followed by a 10 -min extension at $68^{\circ} \mathrm{C}$. By comparing the sequences of the PCR products, three SNPs and a set of two consecutive SNPs were found: G1182T, T1362C, G1515A, and AC1615-1616GT. Of these, the consecutive SNPs (AC1615-1616GT) were thought to change from threonine to valine. We genotyped all polymorphisms of 67 
Table 1. Sequences of the primers used in this study

\begin{tabular}{lll}
\hline Primer name & Sequence & Note \\
\hline F-65 & GAGCACCAAGAATTCGGATC & Searching for polymorphisms \\
R2402 & TGACTCCACAGTAGCACACG & Searching for polymorphisms \\
& TCGTCTTTCATCTGCATCCC & 3'-RACE method \\
F1750 & & \\
& AGCCCACTTCTGTAGCCAAA & RH-mapping \\
RH-F & GGGGAGCGATGTGATAAAGA & RH-mapping \\
RH-R & & \\
& & \\
F1088 & TGACCAGTGTGGTGAACTGC & Genotyping (G1182C) \\
R1315 & TGCTGTCCAAGCCCAGTGTG & Genotyping (G1182C) \\
T1362C-F & TTGGCCTTTCTGGAGCAACC & Genotyping (T1362C) \\
R1424 & AAGAAGCAGGTAATGACCAC & Genotyping (T1362C) \\
F1458 & CTATGTGGTGAAGCTGCTGG & Genotyping (G1515A) \\
G1515A-R & GCTTCCTCCTGTCTCCACTG & Genotyping (G1515A) \\
F1560 & GTTCTGCAGTGACGTGAAGG & Genotyping (AC1615-1616GT) \\
AC1615-1616GT-R & GGAGTCAGAAGAGTGGTTAGCG & Genotyping (AC1615-1616GT) \\
\hline
\end{tabular}

thoroughbred horses for the association study using four primer pairs shown in Table 1 as follows.

G1182T: PCR was performed with $50 \mathrm{ng}$ genomic DNA in a $50-\mu l$ reaction volume, which consisted of $200 \mu \mathrm{M}$ of dNTPs, $25 \mu l$ of $2 \times$ LA Taq GC Buffer II, $0.4 \mu \mathrm{M}$ of each primer (F1088 and R1315), and 1 unit of TaKaRa LA Taq (Takara Bio, Shiga, Japan). After an initial denaturation at $94^{\circ} \mathrm{C}$ for $5 \mathrm{~min}, \mathrm{PCR}$ was performed with 35 cycles of $94^{\circ} \mathrm{C}$ for $60 \mathrm{sec}, 60^{\circ} \mathrm{C}$ for $30 \mathrm{sec}$, and $72^{\circ} \mathrm{C}$ for $120 \mathrm{sec}$. The final cycle was followed by a 10 -min extension at $72^{\circ} \mathrm{C}$. Each PCR product was concentrated and purified using SUPREC-PCR (Takara Bio). Genotyping was performed by direct sequencing with an ABI PRISM 3100 Genetic Analyzer (Applied Biosystems, Foster City, CA).

T1362C: PCR was performed with $50 \mathrm{ng}$ genomic DNA in a $50-\mu l$ reaction volume, which consisted of $200 \mu \mathrm{M}$ of dNTPs, $5 \mu l$ of $10 \times$ Ex Taq Buffer, $0.4 \mu \mathrm{M}$ of each primer (T1362C-F and R1424), and 1.25 units of TaKaRa Ex Taq (Takara Bio). After an initial denaturation at $95^{\circ} \mathrm{C}$ for 5 min, PCR was performed with 35 cycles of $95^{\circ} \mathrm{C}$ for $30 \mathrm{sec}$, $58^{\circ} \mathrm{C}$ for $30 \mathrm{sec}$, and $72^{\circ} \mathrm{C}$ for $30 \mathrm{sec}$. The final cycle was followed by a 10 -min extension at $72^{\circ} \mathrm{C}$. The subsequent analysis was the same as with $\mathrm{G} 1182 \mathrm{~T}$.

G1515A: PCR was performed with $50 \mathrm{ng}$ genomic DNA in a $50-\mu l$ reaction volume, which consisted of $200 \mu \mathrm{M}$ of dNTPs, $5 \mu l$ of $10 \times$ Ex Taq Buffer, $0.4 \mu \mathrm{M}$ of each primer (F1458 and G1515A-R), and 1 unit of TaKaRa Ex Taq. After an initial denaturation at $95^{\circ} \mathrm{C}$ for $5 \mathrm{~min}, \mathrm{PCR}$ was performed with 35 cycles of $95^{\circ} \mathrm{C}$ for $30 \mathrm{sec}, 65^{\circ} \mathrm{C}$ for 30 sec, and $72^{\circ} \mathrm{C}$ for $30 \mathrm{sec}$. The final cycle was followed by a 10 -min extension at $72^{\circ} \mathrm{C}$. Genotyping was carried out using an RFLP method. The PCR product $(10 \mu l)$ was digested with $2.5 \mu \mathrm{l}$ of $10 \times$ TA buffer, $2.5 \mu \mathrm{g}$ of bovine serum albumin, and 2.4 units of HhaI (Toyobo, Osaka, Japan) in a $15-\mu l$ reaction volume. The product was electrophoresed on a $3.0 \%$ agarose gel. As only the G allele was digested with $H$ haI, the GG allele produced two fragments of 302 and 57 bp while the GA allele resulted in 359, 302,
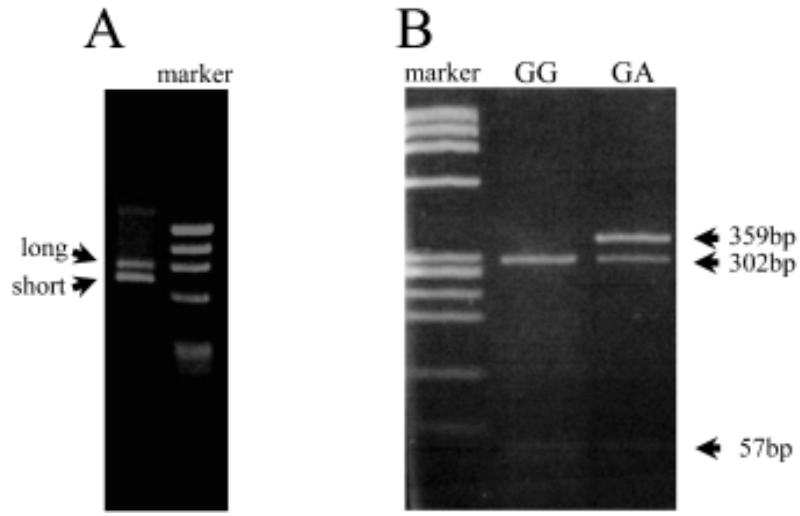

Fig. 1. A. Alternative splicing in the 3' untranslated region, B: SNP (G1515A) demonstrated using a PCR-RFLP method.

A: Three PCR products were produced using the 3'-RACE method with primer F1750. Sequence analysis revealed that the two bands labeled "long" and "short" were specific bands for this gene. The marker was HaeIII-digested øX174 (TaKaRa Bio). B: The PCR products were digested with $H h a \mathrm{I}$ and electrophoresed on a $3.0 \%$ agarose gel. The genotypes are indicated at the top of each lane. Undigested products indicating the AA genotype were not found.

and $57 \mathrm{bp}$ fragments (Fig. 1B). No undigested products indicating the AA genotype were found.

AC1615-1616GT: PCR was performed with $50 \mathrm{ng}$ genomic DNA in a $50-\mu l$ reaction volume, which consisted of $200 \mu \mathrm{M}$ of dNTPs, $5 \mu l$ of $10 \times$ Ex Taq Buffer, $0.2 \mu \mathrm{M}$ of each primer (F1560 and AC1615-1616GT-R), and 2 units of TaKaRa Ex Taq. After an initial denaturation at $95^{\circ} \mathrm{C}$ for 5 min, PCR was performed with 30 cycles of $95^{\circ} \mathrm{C}$ for 30 $\mathrm{sec}, 63^{\circ} \mathrm{C}$ for $30 \mathrm{sec}$, and $72^{\circ} \mathrm{C}$ for $60 \mathrm{sec}$. The final cycle was followed by a 10 -min extension at $72^{\circ} \mathrm{C}$. The subsequent analysis was the same as with G1182T.

The frequencies of the four major alleles were 87.3, 97.0, 91.0 , and $70.9 \%$, and the frequencies of all the polymorphisms were similar to those expected under Hardy-Wein- 
Table 2. Association between haplotypes and anxiety score

\begin{tabular}{|c|c|c|c|c|c|c|}
\hline \multirow[t]{2}{*}{ Haplotype } & \multirow[t]{2}{*}{ Frequency } & \multicolumn{2}{|c|}{ Horses } & \multicolumn{2}{|c|}{ Anxiety score } & \multirow[t]{2}{*}{$P$ value } \\
\hline & & present & absent & present & absent & \\
\hline G-T-G-AC & 0.58 & 60 & 7 & $37.0 \pm 1.0$ & $36.1 \pm 2.9$ & 0.76 \\
\hline G-T-G-GT & 0.29 & 35 & 32 & $36.5 \pm 1.2$ & $37.3 \pm 1.3$ & 0.68 \\
\hline T-T-A-AC & 0.09 & 12 & 55 & $34.3 \pm 1.9$ & $37.5 \pm 1.0$ & 0.17 \\
\hline T-C-G-AC & 0.03 & 4 & 63 & $36.5 \pm 3.1$ & $36.9 \pm 0.9$ & - \\
\hline T-T-G-AC & 0.01 & 1 & 66 & 43.3 & $36.8 \pm 0.9$ & - \\
\hline
\end{tabular}

berg equilibrium. In addition, we estimated haplotype frequencies using the expectation-maximization method with the program SNPAlyze (Dynacom, Mobara, Japan) as shown in Table 2.

As reported previously [13], RH mapping on an equine 5000-rad RH panel [3] was performed as follows. PCR was carried out in a 10- $\mu l$ reaction volume, which consisted of $40 \mathrm{ng}$ DNA, $250 \mu \mathrm{M}$ of dNTPs, $1 \mu \mathrm{l}$ of $10 \times$ PCR Gold Buffer, $0.5 \mu \mathrm{M}$ of each primer (RH-F and RH-R), $3.0 \mathrm{mM}$ $\mathrm{MgCl}_{2}$, and 0.4 units AmpliTaq Gold DNA Polymerase (Applied Biosystems). The PCR products were separated by electrophoresis on a $3.0 \%$ agarose gel and scored manually. Two-point analysis using the program RHMAPPER indicated that the serotonin transporter gene was located 26.92 cR from neurofibromin 1 (NF1; lod $>3.0$ ), which had been previously mapped to ECA 11q12-q13 [2, 4, 8]. The assignment of the serotonin transporter gene is in agreement with the comparative map of the horse and human genomes (HSA 17q11.1-q12) [18].

We studied 67 thoroughbred horses and administered the questionnaire survey to their caretakers adopted in our previous report [10]. The questionnaire involved grading 20 temperament traits on 9-point scales. Factor analysis showed that factor 1, designated as "anxiety", had seven question items ('Nervousness', 'Excitability', 'Panic', 'Inconsistent emotionality', 'Vigilance', 'Skittishness', and 'Timidity') and the sum of their scores was assigned as the anxiety score. Although we used Student's $t$-test to investigate the influence of each haplotype on equine anxiety trait, no significant differences regarding the three most frequent haplotypes (i.e., G-T-G-AC, G-T-G-GT, and T-T-A-AC) were found, as shown Table 2.

In conclusion, we determined the sequence and chromosome location of the serotonin transporter gene, and identified four polymorphisms. Although no significant association was found between each haplotype and equine anxiety trait in 67 thoroughbred horses, this anxiety trait should be given priority among equine temperament traits to be investigated, as it can be assessed more reliably and accurately than other temperament traits using either questionnaires or behavior tests [9-11, 17]; this is in addition to the importance of the anxiety trait in various human-horse relationships.

ACKNOWLEDGEMENT. This work was supported by a grant-in-aid for scientific research from the Ministry of Education, Science, Sports, Culture, and Technology, Japan
(No. 17380167).

\section{REFERENCES}

1. Battersby, S., Ogilvie, A. D., Blackwood, D. H., Shen, S., Muqit, M. M., Muir, W. J., Teague, P., Goodwin, G. M. and Harmar, A. J. 1999. J. Neurochem. 72: 1384-1388.

2. Caetano, A. R., Shiue, Y. L., Lyons, L. A., O'Brien, S. J., Laughlin, T. F., Bowling, A. T. and Murray, J. D. 1999. Genome Res. 9: 1239-1249.

3. Chowdhary, B. P., Raudsepp, T., Honeycutt, D., Owens, E. K., Piumi, F., Guerin, G., Matise, T. C., Kata, S. R., Womack, J. E. and Skow, L. C. 2002. Mamm. Genome 13: 89-94.

4. Chowdhary, B. P., Raudsepp, T., Kata, S. R., Goh, G., Millon, L. V., Allan, V., Piumi, F., Guerin, G., Swinburne, J., Binns, M., Lear, T. L., Mickelson, J., Murray, J., Antczak, D. F., Womack, J. E. and Skow, L. C. 2003. Genome Res. 13: 742751 .

5. Cloninger, C. R. 1987. Arch. Gen. Psychiatry 44: 573-588.

6. Ito, H., Nara, H., Inoue-Murayama, M., Shimada, M. K., Koshimura, A., Ueda, Y., Kitagawa, H., Takeuchi, Y., Mori, Y., Murayama, Y., Morita, M., Iwasaki, T., Ota, K., Tanabe, Y. and Ito, S. 2004. J. Vet. Med. Sci. 66: 815-820.

7. Lesch, K. P., Bengel, D., Heils, A., Sabol, S. Z., Greenberg, B. D., Petri, S., Benjamin, J., Muller, C. R., Hamer, D. H. and Murphy, D. L. 1996. Science 274: 1527-1531.

8. Mariat, D., Oustry-Vaiman, A., Cribiu, E. P., Raudsepp, T., Chowdhary, B. P. and Guerin, G. 2001. Cytogenet. Cell Genet. 92: 144-148

9. McCall, C. A., Hall, H., McElhenney, W. H. and Cummings, K. A. 2006. Appl. Anim. Behav. Sci. 96: 115-127.

10. Momozawa, Y., Kusunose, R., Kikusui, T., Takeuchi, Y. and Mori, Y. 2005. Appl. Anim. Behav. Sci. 92: 77-84.

11. Momozawa, Y., Ono, T., Sato, F., Kikusui, T., Takeuchi, Y., Mori, Y. and Kusunose, R. 2003. Appl. Anim. Behav. Sci. 84: 127-138.

12. Momozawa, Y., Takeuchi, Y., Kusunose, R., Kikusui, T. and Mori, Y. 2005. Mamm. Genome 16: 538-544.

13. Momozawa, Y., Takeuchi, Y., Tozaki, T., Kikusui, T., Hasegawa, T., Raudsepp, T., Chowdhary, B. P., Kusunose, R. and Mori, Y. 2005. Anim. Genet. 36: 190.

14. Murphy, D. L., Lerner, A., Rudnick, G. and Lesch, K. P. 2004. Mol. Interv. 4: 109-123.

15. Reif, A. and Lesch, K. P. 2003. Behav. Brain Res. 139: 1-20.

16. Takeuchi, Y. and Houpt, K. A. 2003. Vet. Clin. North Am. Small Anim. Pract. 33: 345-363.

17. Visser, E. K., van Reenen, C. G., Rundgren, M., Zetterovist, M., Morgan, K. and Blokhuis, H. J. 2003. Equine Vet. J. 35 : 176-183.

18. Yang, F., Fu, B., O'Brien, P. C., Nie, W., Ryder, O. A. and Ferguson-Smith, M. A. 2004. Chromosome Res. 12: 65-76. 